\title{
DESKRIPSI PEMAHAMAN CYBERBULLYING DI MEDIA SOSIAL PADA MAHASISWA
}

\author{
Fasya Syifa Mutma \\ Program Pasca Sarjana, Strategic Corporate Communication \\ London School of Public Relations, Jakarta \\ Email :fasya.syifa@upj.ac.id
}

\begin{abstract}
The development of internet technology and social media is accelerating the process of disseminating information. This certainly makes it easier for human life. But, besides that, the rapid pace of information technology can have a negative impact if it is not put to good use. At the moment there is a rampant cyberbullying case, which is the bullying that occurs through cyber media, in this case, social media. Cyberbullying has a bad impact on victims such as causing depression, so that the worst is causing death due to suicide. Cyberbullying is often a big problem both in the national and global order. There have been many cases that have occurred, the most numerous being teenagers who committed suicide due to experiencing cyberbully. Because of this, researchers are interested in researching more about cyberbullying. In this study, researchers wanted to find out how much the level of understanding of adolescents towards cyberbullying behavior. This study uses a positivistic paradigm with data collection methods, namely questionnaire survey. The sample of this study were students from one of the universities in South Tangerang.
\end{abstract}

Keywords : cyberbullying, bullying, social media

\begin{abstract}
Abstrak
Perkembangan teknologi internet dan media sosial semakin mempercepat proses penyebaran informasi. Hal ini tentu mempermudah manusia kehidupan manusia. Namun pesatnya teknologi informasi dapat berdampak negatif jika tidak dimanfaatkan dengan baik. Saat ini tengah marak kasus cyberbullying, yaitu perlakuan bully yang terjadi melalui media cyber dalam hal ini yaitu media sosial. Cyberbullying memiliki dampak yang buruk terhadap korban seperti menyebabkan depresi, hingga yang terparah yaitu menyebabkan kematian karena bunuh diri. Cyberbullying kerap menjadi masalah besar baik di tatanan nasional hingga global. Telah banyak kasus yang terjadi, yang paling banyak yaitu remaja yang bunuh diri karena mengalami cyberbully. Karena hal tersebut, peneliti tertarik untuk meneliti lebih lanjut tentang cyberbullying. Dalam penelitian ini peneliti ingin mengetahui seberapa besar tingkat pemahaman remaja terhadap perilaku cyberbullying. Penelitian ini menggunakan paradigma positivistik dengan metode pengumpulan data yaitu survei kuesioner. Sampel penelitian ini adalah mahasiswa dari salah satu Universitas di Tangerang Selatan.
\end{abstract}

Kata Kunci : cyberbullying, bullying, media sosial 


\section{PENDAHULUAN}

Perkembangan zaman semakin memicu perkembangan ilmu pengetahuan dan teknologi. Perkembangan tersebut disebabkan dampak globalisasi di seluruh dunia. Globalisasi dan perkembangan teknologi tersebut seperti sudah menjadi bagian dari kehidupan manusia yang tidak dapat dipisahkan. Perkembangan teknologi ini salah satunya yaitu Internet (Giovanni, 2014:1).

Internet memungkinkan semua orang terhubung satu sama lain, tanpa adanya batasan ruang dan waktu. Saat ini masyarakat memanfaatkan internet bukan hanya untuk sekadar terhubung dengan pengguna lainnya di seluruh dunia, namun juga untuk pemenuhan kebutuhan atas segala aspek dalam kehidupannya. Pengguna internet pun tidak hanya orang dewasa yang mungkin sudah mengerti tentang baik dan buruknya suatu hal, namun internet juga kerap digunakan oleh remaja, hingga anak-anak (Aulia, 2014:1).

Menurut data statistic Kementerian Komunikasi dan Informasi, pengguna internet di seluruh dunia yaitu sebanyak 3 miliar orang tahun 2015. Kemudian pada tahun 2018 nanti, diperkirakan pengguna internet mencapai 3,6 miliar orang (Kominfo, 2014).

Kementerian Komunikasi dan Informatika (Kemkominfo) menyatakan bahwa pengguna internet di Indonesia hingga saat ini telah mencapai 82 juta orang. Dengan capaian tersebut, Indonesia mendapat peringkat ke- 8 di dunia. Kemudian dari jumlah pengguna internet terebut, $80 \%$ diantaranya adalah remaja berusia 15-19 tahun (Kominfo, 2016).

Teknologi dapat mempermudah manusia dalam menjalani kehidupannya, serta dapat meningkatkan kualitas hidupnya. Tetapi disamping banyaknya manfaat yang ditimbulkan dari keberadaan internet, dampak buruk juga telah terjadi karena perkembangan teknologi internet ini. Seperti contohnya pornografi, kasus penipuan, hingga kekerasasn yang semua terjadi dalam dunia maya (Kominfo, 2016). Fenomena yang marak terjadi di dunia maya saat ini yaitu cyberbullying.

Media sosial yang merupakan pengembangan dari internet juga turut andil dalam mendukung aksi cyberbullying. Media sosial atau situs jejaring sosial adalah suatu media atau sarana untuk berbagi data atau informasi personal, saling berkomunikasi, saling berbagi cerita, memposting tulisan, gambar atau video. Media sosial yang kini digunakan oleh hampir semua pengguna internet yaitu seperti Facebook, Twitter, Ask.fm, Instagram, Path, dan lain-lain.

Tindak Cyberbullying tidak bisa diremehkan. Angkanya terus menanjak. Yang mengkhawatirkan adalah sebanyak 90\% remaja yang pernah menyaksikan cyberbullying mengaku tidak mempedulikannya (Tim Internet Sehat, 2012).

Menurut studi yang dilakukan Online College.org belum lama ini, sebanyak $42 \%$ remaja pengguna sosial media mengaku pernah mengalami cyberbullying dalam beberapa tahun terakhir (Tim Internet Sehat, 2012).

Perkembangan yang pesat dalam teknologi internet menyebabkan kejahatan baru, yaitu cyberbullying. Telah banyak kasus cyberbullying yang berdampak buruk bagi pengguna internet, bahkan tidak sedikit dari mereka yang nekat mengakhiri hidupnya karena tidak 
tahan menerima perlakuan bully. Menurut riset terdahulu, satu dari 5 anak korban cyberbullying berpikir untuk melakukan bunuh diri. Dalam setahun, ada sekitar 4500 anak yang bunuh diri karena tindak cyberbullying (Tim Internet Sehat, 2012).

Cyberbullying berasal dari kata bully. Dalam bahasa Indonesia, secara harfiah kata bully berarti penggertak, orang yang mengganggu orang lemah. (Rudi, 2010:3). Contoh perilaku bullying antara lain mengejek, menyebarkan rumor, menghasut, mengucilkan, menakut-nakuti (intimidasi), mengancam, menindas, memalak, atau menyerang secara fisik (mendorong, menampar, memukul).

Bullying tentu mengakibatkan dampak yang negatif, memang terkadang bagi pelaku bully, tindakan bullying yang dilakukannya kadang tidak Ia sadari. Bullying dapat menimbulkan perasaan tidak aman, terisolasi, perasaan harga diri yang rendah, depresi atau menderita stress yang dapat berakhir dengan bunuh diri seperti kasus-kasus yang marak terjadi di seluruh belahan dunia (Rudi, 2010:5).

Sehubungan dengan perkembangan teknologi informasi dan komunikasi, seperti contohnya yaitu internet, menyebabkan perilakubullying semakin mudah dilakukan. Internet kini dijadikan media untuk melakukan bully oleh oknum-oknum yang tidak bertanggungjawab. Bullying melalui internet biasa disebut cyberbullying.

Cyberbullying merupakan perlakuan bullying melalui internet dan teknologi digital. Tujuannya adalah untuk mengganggu, mengancam, mempermalukan, menghina, mengucilkan secara sosial, atau merusak reputasi orang lain (Rudi, 2010:15).
Cyberbullying merupakan intimidasi yang dilakukan seseorang pada orang lain yang dilakukan melalui chatroom, media sosial, e-mail, website dalam bentuk seperti fitnah, penghinaan, pengancaman atau dibocorkannya aib mengenai seseorang (Giovanni, 2014:2).

Fenomena cyberbullying tentu didukung oleh teknologi yang kini terus menerus berkembang. Pengetahuan tentang internet dan tentang cyberbullying sudah seharusnya dimiliki oleh semua pengguna internet, agar semua dapat menghindari tindakan tersebut. Namun, pada kenyataannya tidak semua orang dapat membedakan mana perilaku yang merupakan cyberbullying mana yang tidak. Sebagian dari mereka bahkan tidak menyadari tentang adanya tindak cyberbullying di internet. Seperti yang terjadi di kalangan mahasiswa Universitas Pembangunan Jaya (UPJ) yang rata-rata berstatus ekonomi menengah keatas, yang mempunyai gadget dengan beragam macam fitur dan mempunyai akses data untuk mengakses internet. Kemudian sebagian besar dari mereka merupakan pengguna internet, bahkan mereka merupakan pengguna aktif, yang setiap harinya selalu mengakses internet. Semua yang ada di internet dimanfaatkan oleh mahasiswa UPJ untuk menunjang kemudahan hidupnya, seperti berkomunikasi, mencari dan berbagi informasi terkait mata kuliah maupun diluar mata kuliah, saling berbagi cerita, dan lain-lain. Tujuan penelitian ini adalah untuk mengetahui sejauh mana pemahaman tentang cyberbullying di media sosial pada mahasiswa.

\section{Efek Komunikasi Massa - Teori Determinisme Teknologi}

Saputro, (2011:70) menyatakan bahwa secara garis besar, determinisme teknologi 
menjadi seperti yang dijelaskan diatas karena ketiadaan kontrol manusia terhadap perkembangan dari teknologi. Hal ini bukan disebabkan oleh ketidakmampuan manusia dalam mengontrol teknologi tersebut, melainkan karena memang manusia tidak peduli terhadapnya. Artinya, manusia menerima begitu saja teknologi yang dipakainya.

Bersandar pada teori determinisme teknologi, terlihat jelas bahwa masyarakat zaman sekarang cenderung terdominasi oleh teknologi. Hal ini semakin memperkuat dasar teori ini, bahwa benar teknologi mempengaruhi penggunanya. Seperti contohnya sekarang orang-orang semakin terpaku dengan gadgetnya yang semakin berkembang zaman semakin canggih. Melihat padakasus-kasus cyberbullying yang marak terjadi, jelas sekali bahwa pelaku dan korban cyberbullying ini seakan telah terdominasi oleh media sosial sehingga mereka terus menerus mengakses media sosial.

\section{Internet \& Media Sosial}

Kemunculan internet kemudian memicu munculnya teknologi baru yaitu media sosial yang merupakan situs dimana sorang bisa memiliki web page atau akun pribadi. Media sosial digunakan untuk saling berbagi informasi, pengalaman, dan cerita, dan saling berkomunikasi. Media sosial terbesar contohnya adalah Facebook, plurk, my space, Instagram, Path, Ask.fm dan Twitter. Jika media tradisional menggunakan media cetak dan media broadcast, media sosial menggunakan media baru yaitu internet. Media sosial mengajak kita untuk berpartisipasi secara aktif dengan memberi respon terhadap segala aktifitas yang dilakukan orang lain di media sosial (Lesmana, 2012).

\section{Bullying}

Professor Dan Olweus mengatakan bahwa terdapat dua tipe bullying yaitu secara langsung (direct bullying) misalnya penyerangan secara fisik dan perilaku secara tidak langsung (indirect bullying) misalnya pengucilan secara sosial. Jadi, bullying adalah perilaku agresif dan negatif seseorang atau sekelompok orang secara berulang kali yang menyalahgunakan ketidakseimbangan kekuatan dengan tujuan untuk menyakiti targetnya (korban) secara mental atau secara fisik (Rudi, 2010:4).

Perilaku bullying antara lain kekerasan fisik (mendorong, menendang, memukul, menampar). Perilaku bullying secara verbal (Misalnya panggilan yang bersifat mengejek atau celaan). Perilaku bullying secara mental (mengancam, intimidasi, pemerasan, pemalakan). Perilaku bullying secara sosial, misalnya menghasut dan mengucilkan (Rudi, 2010:5).

Pola perilaku para bully ini cenderung impulsif, agresif, intimidatif dan suka memukul. Motivasi seseorang untuk melakukan bullying bisa berdasarkan kebencian, perasaan iri dan dendam. Bisa juga karena untuk menyembunyikan rasa malu dan kegelisahan, atau untuk mendorong rasa percaya diri dengan menganggap orang lain tidak ada artinya. Bullying tentu mengakibatkan dampak yang negatif, memang terkadang bagi pelaku bully, tindakan bullying yang dilakukannya kadang tidak Ia sadari (Rudi, 2010:5).

\section{Cyberbullying}

Bullying yang terjadi di dunia maya memiliki beberapa karakteristik seperti, materinya biasanya berupa tulisan, foto, atau video yang dapat didistribusikan secara worldwide 
dan seringkali tidak bisa dihilangkan, kemudian pelaku bullying biasanya bersifat anonim, menggunakan nama lain atau berpura-pura sebagai orang lain, lalu kejadiannya bisa kapan saja dan dimana saja, karena segala sesuatu yang dilakukan di dunia maya tidak terbatas ruang dan waktu (Rudi, 2010:15).

Kejahatan cyberbullying banyak mengambil target remaja dan anak-anak dikarenakan kehidupan dua jenjang usia tersebut masih sangat fasih dan dekat dengan teknologi digital, ditambah lagi pada usia tersebut mereka belum bisa membedakan mana yang baik mana yang buruk (Sudarwanto, 2009:9).

Cyberbullying dapat menyebabkan korban memiliki perasaan harga diri rendah, depresi atau menderita stress yang dapat berakhir dengan bunuh diri seperti kasus-kasus yang marak terjadi di seluruh belahan dunia (Rudi, 2010:5).

Dalam buku Save Our Children From School Bullying, menyebutkan macam-macam jenis cyberbullying sebagai berikut (Dewi dan Purwanti, 2014:4):

1. Flaming (terbakar): yaitu mengirimkan pesan teks yang isinya merupakan katakata yang penuh amarah dan frontal.

2. Harassment (gangguan): pesan-pesan yang berisi gangguan pada Email, sms, maupun pesan teks di jejaring sosial dilakukan secara terus menerus

3. Denigration (pencemaran nama baik): yaitu proses mengumbar keburukan seseorang di internet dengan maksud merusak reputasi dan nama baik orang tersebut

4. Impersonation (peniruan): berpura-pura menjadi orang lain dan mengirimkan pesan-pesan atau status yang tidak baik
5. Outing: menyebarkan rahasia orang lain, atau foto-foto pribadi orang lain

6. Trickery (tipu daya): membujuk seseorang dengan tipu daya agar mendapatkan rahasia atau foto pribadi orang tersebut

7. Exclusion (pengeluaran): secara sengaja dan kejam mengeluarkan seseorang dari grup online.

8. Cyberstalking: mengganggu dan mencemarkan nama baik seseorang secara intens sehingga membuat ketakutan besar pada orang tersebut.

Dalam penelitian yang dilakukan Price dan Dalgleish (2010) pada 548 remaja Australia dan juga didukung oleh penelitan-penelitian lainnya (Patchin, 2009), bentuk-bentuk cyberbullying yang ditemukan antara lain: (Akbar dan Utari, 2015:12-14)

a. Called Name (Pemberian Nama Negatif): Memanggil orang dengan nama negatif di media sosial.

b. Image of Victim Spread (Penyebaran Foto): Menyebarkan foto aib orang lain di media sosial.

c. Threatened Physical Harm (Mengancam Keselamatan Fisik): Mengancam orang lain di media sosial.

d. Opinion Slammed (Pendapat Yang Merendahkan): Merendahkan atau menghina orang lain di media sosial.

\section{METODE PENELITIAN}

Dalam penelitian ini jenis dan sifat penelitiannya adalah penelitian kuantitatif dengan sifat deskriptif. Pendekatan atau paradigma yang digunakan dalam penelitian ini adalah pendekatan positivistik. Sedangkan, 
teknik yang digunakan dalam penelitian ini adalah teknik survei.

Dalampenelitianinipenelitimenggunakan sistem random sampling. Teknik pengumpulan data dengan menggunakan kuesioner yang disebarkan kepada sampel. Teknik analisa data menggunakan analisa deskriptif.

\section{HASIL DAN PEMBAHASAN}

\section{Usia}

\begin{tabular}{|c|c|c|c|c|c|}
\hline \multicolumn{2}{|c|}{} & $\begin{array}{c}\text { Fre- } \\
\text { quency }\end{array}$ & Percent & $\begin{array}{c}\text { Valid } \\
\text { Percent }\end{array}$ & $\begin{array}{c}\text { Cumulative } \\
\text { Percent }\end{array}$ \\
\hline \multirow{4}{*}{$* \overline{\bar{N}}$} & 17 & 1 & 1.7 & 1.7 & 1.7 \\
\cline { 2 - 6 } & 18 & 9 & 15.0 & 15.0 & 16.7 \\
\cline { 2 - 6 } & 19 & 24 & 40.0 & 40.0 & 56.7 \\
\cline { 2 - 6 } & 20 & 12 & 20.0 & 20.0 & 76.7 \\
\cline { 2 - 6 } & 21 & 10 & 16.7 & 16.7 & 93.3 \\
\cline { 2 - 6 } & 22 & 4 & 6.7 & 6.7 & 100.0 \\
\hline \multicolumn{2}{|c|}{ Total } & $\mathbf{6 0}$ & $\mathbf{1 0 0 . 0}$ & $\mathbf{1 0 0 . 0}$ & \\
\hline
\end{tabular}

Dari tabel diatas terbukti bahwa pengisi kuesioner terbanyak yang juga merupakan pengguna media sosial adalah usia 18-21 tahun, karena pada usia tersebut sedang marak-maraknya mengikuti tren. Seperti contohnya tren menggunakan media sosial.

\section{Media sosial yang sering digunakan}

\begin{tabular}{|l|l|c|}
\hline No & \multicolumn{1}{|c|}{ Media Sosial } & Pengguna \\
\hline 1 & Facebook & 31 \\
\hline 2 & Ask.fm & 14 \\
\hline 3 & Twitter & 32 \\
\hline 4 & Instagram & 58 \\
\hline 5 & Path & 53 \\
\hline 6 & Email & 54 \\
\hline 7 & YouTube & 45 \\
\hline
\end{tabular}

Menurut data diatas, terlihat bahwa Instagram merupakan media yang paling sering digunakan oleh hampir seluruh responden, meskipun ada yang menggunakan lebih dari satu media sosial.
3. Apa pernah melihat tindak cyberbullying

\begin{tabular}{|c|c|c|c|c|c|}
\hline & $\begin{array}{c}\text { Fre- } \\
\text { quency }\end{array}$ & Percent & $\begin{array}{l}\text { Valid } \\
\text { Percent }\end{array}$ & $\begin{array}{c}\text { Cumulative } \\
\text { Percent }\end{array}$ \\
\hline \multirow{3}{*}{$\frac{i}{\pi}$} & Ya & 57 & 95.0 & 95.0 & 95.0 \\
\hline & Tidak & 3 & 5.0 & 5.0 & 100.0 \\
\hline & Total & 60 & 100.0 & 100.0 & \\
\hline
\end{tabular}

Dari data diatas terbukti bahwa hampir semua pengisi kuesinoner pernah melihat tindak cyberbullying. Karena pengisi kuesioner merupakan pengguna media sosial dan media sosial merupakan tempat terbanyak terdapatnya cyberbullying.

Hal ini sesuai dengan teori yang dikatakan oleh Dewi \& Purwanti, 2014 yaitu "Cyberbullying marak terjadi di media sosial", sehingga pengguna media sosial sudah pasti sering melihat tindak cyberbullying tersebut.

\section{Apa pernah mengalami cyberbullying}

\begin{tabular}{|c|c|c|c|c|c|}
\hline & $\begin{array}{l}\text { Freq- } \\
\text { uency }\end{array}$ & $\begin{array}{l}\text { Per- } \\
\text { cent }\end{array}$ & $\begin{array}{c}\text { Valid } \\
\text { Per-cent }\end{array}$ & $\begin{array}{c}\text { Cumulative } \\
\text { Percent }\end{array}$ \\
\hline \multirow{3}{*}{$\frac{i}{\frac{0}{\pi}}$} & Pernah & 15 & 25.0 & 25.0 & 25.0 \\
\hline & $\begin{array}{l}\text { Tidak } \\
\text { Pernah }\end{array}$ & 45 & 75.0 & 75.0 & 100.0 \\
\hline & Total & 60 & 100.0 & 100.0 & \\
\hline
\end{tabular}

Dari data diatas dapat disimpulkan bahwa sebagian besar pengguna media sosial sudah dapat menggunakan media sosial dengan baik sehingga mengurangi resiko terkenanya tindak cyberbullying, namun sebagian kecil pernah mengalaminya di media sosial karena pada dasarnya mereka tidak dapat menahan respon buruk yang terjadi di media sosial sehingga menganggapnya sebagai tindak cyberbullying.

Hal ini sesuai dengan teori yang diungkapkan oleh Rudi, 2010, "Bullying tentu mengakibatkan dampak yang negatif, memang terkadang bagi pelaku bully, tinda- 
kan bullying yang dilakukannya kadang tidak Ia sadari. Sementara bagi orang lain, sekali aksi negative terjadi padanya dapat menjadi pengalaman bullying", sama saja jika dikaitkan dengan cyber, sehingga pengguna media sosial kadang salah mengartikan respon dimedia sosial dan kadang menganggapnya sebagai tindak cyberbullying.

\section{Apa pernah melakukan cyberbullying}

\begin{tabular}{|c|l|c|c|c|c|}
\hline \multicolumn{2}{|l|}{} & $\begin{array}{c}\text { Freq- } \\
\text { uency }\end{array}$ & $\begin{array}{c}\text { Per- } \\
\text { cent }\end{array}$ & $\begin{array}{c}\text { Valid } \\
\text { Percent }\end{array}$ & $\begin{array}{c}\text { Cumulative } \\
\text { Percent }\end{array}$ \\
\hline \multirow{3}{*}{$\frac{\text { 을 }}{\sqrt{5}}$} & \begin{tabular}{l} 
Pernah \\
\cline { 2 - 6 }
\end{tabular} & 15 & 25.0 & 25.0 & 25.0 \\
\cline { 2 - 6 } & Pernah & 44 & 73.3 & 73.3 & 98.3 \\
\cline { 2 - 6 } & Missing & 1 & 1.7 & 1.7 & 100.0 \\
\cline { 2 - 6 } & Total & $\mathbf{6 0}$ & $\mathbf{1 0 0 . 0}$ & $\mathbf{1 0 0 . 0}$ & \\
\hline
\end{tabular}

Dari data diatas dapat disimpulkan bahwa sebagian besar mahasiswa UPJ tidak pernah melakukan cyberbullying, kemudian sebagian kecil pernah melakukannya. Hal ini dikarenakan orang cyberbullying dilatarbelakangi oleh berbagai macam hal seperti marah, sakit hati, balas dendam, frustasi, haus kekuasaan, karena bosan, ingin cari hiburan, karena kemudahan teknologi internet yang cepat, tidak terbatas ruang, dan dapat diakses 24 jam yang dapat terjadi kepada pelaku-pelaku cyberbullying.

Hal ini sesuai dengan teori yang diungkapkan oleh Rudi, 2010, bahwa alasan orang melakukan cyberbullyig adalah karena marah, sakit hati, balas dendam, frustasi, haus kekuasaan, dan juga karena kemudahan teknologi.

6. Di media sosial mana sering terdapat tindak cyberbullying

\begin{tabular}{|l|l|ll|}
\hline No & Media Sosial & \multicolumn{1}{c|}{ Frekuensi } \\
\hline 1 & Facebook & 23 & \\
\hline
\end{tabular}

\begin{tabular}{|l|l|l|}
\hline 2 & Ask.fm & 27 \\
\hline 3 & Twitter & 15 \\
\hline 4 & Instagram & 43 \\
\hline 5 & Path & 5 \\
\hline 6 & Email & 7 \\
\hline 7 & YouTube & 19 \\
\hline
\end{tabular}

Menurut data diatas, dari 60 responden mahasiswa UPJ, media sosial yang paling banyak berisi tindak cyberbullying adalah Instagram. Tindak cyberbullying yang sering terjadi di Instagram adalah komentar negatif pada posting-an orang, dan kontenkonten yang berbau penghinaan bagi orang lain.

7. Sebab orang melakukan cyberbullying (marah)

\begin{tabular}{|c|c|c|c|c|c|}
\hline & $\begin{array}{l}\text { Freq- } \\
\text { uency }\end{array}$ & $\begin{array}{l}\text { Per- } \\
\text { cent }\end{array}$ & $\begin{array}{l}\text { Valid } \\
\text { Percent }\end{array}$ & $\begin{array}{c}\text { Cumulative } \\
\text { Percent }\end{array}$ \\
\hline \multirow{5}{*}{$\frac{i \frac{0}{5}}{5}$} & $\begin{array}{l}\text { Sangat Tidak } \\
\text { Setuju }\end{array}$ & 1 & 1.7 & 1.7 & 1.7 \\
\hline & Tidak Setuju & 16 & 26.7 & 26.7 & 28.3 \\
\hline & Setuju & 39 & 65.0 & 65.0 & 93.3 \\
\hline & $\begin{array}{l}\text { Sangat } \\
\text { Setuju }\end{array}$ & 4 & 6.7 & 6.7 & 100.0 \\
\hline & Total & 60 & 100.0 & 100.0 & \\
\hline
\end{tabular}

Dari data ini, pernyataan "setuju" lebih besar pernyataan lainnya. Hal ini menunjukkan kebenaran bahwa marah bisa menjadi penyebab dan motivasi orang untuk melakukan cyberbullying. Karena orang yang marah dapat menjadi emosi kemudian nekat melakukan cyberbullying kepada orang yang membuatnya marah atau bahkan kepada orang lain hanya untuk melampiaskan amarahnya.

Hal ini relevan dengan teori yang diungkapkan oleh Rudi, 2010, bahwa marah merupakan salah satu alasan orang melakukan bullying maupun cyberbullying. 
8. Sebab orang melakukan cyberbullying (sakit hati)

\begin{tabular}{|c|l|c|c|c|c|}
\hline \multicolumn{2}{|c|}{} & $\begin{array}{c}\text { Freq- } \\
\text { uency }\end{array}$ & $\begin{array}{c}\text { Per- } \\
\text { cent }\end{array}$ & $\begin{array}{c}\text { Valid } \\
\text { Percent }\end{array}$ & $\begin{array}{c}\text { Cumulative } \\
\text { Percent }\end{array}$ \\
\hline \multirow{4}{*}{$\begin{array}{l}\text { Sangat Tidak } \\
\text { Setuju }\end{array}$} & 1 & 1.7 & 1.7 & 1.7 \\
\cline { 2 - 6 }$>\overline{\frac{\bar{S}}{5}}$ & Tidak Setuju & 6 & 10.0 & 10.0 & 11.7 \\
\cline { 2 - 6 } & Setuju & 43 & 71.7 & 71.7 & 83.3 \\
\cline { 2 - 6 } & $\begin{array}{l}\text { Sangat } \\
\text { Setuju }\end{array}$ & 10 & 16.7 & 16.7 & 100.0 \\
\cline { 2 - 6 } & Total & $\mathbf{6 0}$ & $\mathbf{1 0 0 . 0}$ & $\mathbf{1 0 0 . 0}$ & \\
\hline
\end{tabular}

Dari data diatas dapat disimpulkan bahwa pernyataan "setuju" lebih besar dari pernyataan lainnya. Hal ini menunjukkan kebenaran bahwa sakit hati bisa menjadi penyebab dan motivasi orang untuk melakukan cyberbullying. Karena orang yang sakit hati memiliki niat yang besar untuk dapat melegakan perasaan sakitnya dan akhirnya melakukan cyberbullying.

Hal ini sesuai dengan teori yang diungkapkan oleh Rudi, 2010, bahwa sakit hati merupakan salah satu alasan orang melakukan bullying maupun cyberbullying.

9. Sebab melakukan cyberbullying (frustasi)

\begin{tabular}{|c|c|c|c|c|c|}
\hline & $\begin{array}{l}\text { Freq- } \\
\text { uency }\end{array}$ & $\begin{array}{l}\text { Per- } \\
\text { cent }\end{array}$ & $\begin{array}{l}\text { Valid } \\
\text { Percent }\end{array}$ & $\begin{array}{c}\text { Cumulative } \\
\text { Percent }\end{array}$ \\
\hline \multirow{5}{*}{$\frac{\text { 음 }}{5}$} & $\begin{array}{l}\text { Sangat Tidak } \\
\text { Setuju }\end{array}$ & 7 & 11.7 & 11.7 & 11.7 \\
\hline & Tidak Setuju & 22 & 36.7 & 36.7 & 48.3 \\
\hline & Setuju & 28 & 46.7 & 46.7 & 95.0 \\
\hline & $\begin{array}{l}\text { Sangat } \\
\text { Setuju }\end{array}$ & 3 & 5.0 & 5.0 & 100.0 \\
\hline & Total & 60 & 100.0 & 100.0 & \\
\hline
\end{tabular}

Dari data ini, pernyataan "setuju" lebih besar dari pernyataan lain. Hal ini menunjukkan kebenaran bahwa frustasi bisa menjadi penyebab dan motivasi orang untuk melakukan cyberbullying. Karena orang frustasi memiliki perasaan yang tidak menentu sehingga terkadang ia mencari pelampiasan untuk melegakan pikirannya yang sedang frustasi.

Hal ini sesuai dengan yang diungkapkan oleh Rudi, 2010, bahwa frustasi merupakan salah satu alasan orang melakukan bullying maupun cyberbullying.

10. Sebab orang melakukan cyberbullying (haus kekuasaan)

\begin{tabular}{|c|l|c|c|c|c|}
\hline \multicolumn{2}{|c|}{} & $\begin{array}{c}\text { Freq- } \\
\text { uency }\end{array}$ & $\begin{array}{c}\text { Per- } \\
\text { cent }\end{array}$ & $\begin{array}{c}\text { Valid } \\
\text { Percent }\end{array}$ & $\begin{array}{c}\text { Cumulative } \\
\text { Percent }\end{array}$ \\
\hline \multirow{2}{*}{$\begin{array}{l}\text { Sangat Tidak } \\
\text { Setuju }\end{array}$} & 1 & 1.7 & 1.7 & 1.7 \\
\cline { 2 - 6 } & Tidak Setuju & 18 & 30.0 & 30.0 & 31.7 \\
\cline { 2 - 6 } & Setuju & 25 & 41.7 & 41.7 & 73.3 \\
\cline { 2 - 6 } & $\begin{array}{l}\text { Sangat } \\
\text { Setuju }\end{array}$ & 16 & 26.7 & 26.7 & 100.0 \\
\cline { 2 - 6 } & Total & 60 & $\mathbf{1 0 0 . 0}$ & $\mathbf{1 0 0 . 0}$ & \\
\hline
\end{tabular}

Dari data diatas dapat disimpulkan bahwa pernyataan "setuju" lebih besar dari pernyataan lain. Hal ini menandakan kebenaran bahwa ingin menunjukkan kekuasaan atau kekuatan bisa menjadi penyebab dan motivasi orang untuk melakukan cyberbullying. Karena terkadang pelaku cyberbullying selalu ingin menunjukkan bahwa dirinya kuat dan berkuasa sehingga ia menindas dan menyakiti orang lain.

Hal ini sesuai dengan teori yang diungkapkan oleh Rudi, 2010, bahwa ingin menunjukkan kekuasaan atau kekuatan merupakan salah satu alasan orang melakukan bullying maupun cyberbullying.

11. Sebab orang melakukan cyberbullying (tidak harus tatap muka)

\begin{tabular}{|c|l|c|c|c|c|}
\hline \multicolumn{2}{|c|}{} & $\begin{array}{c}\text { Freq- } \\
\text { uency }\end{array}$ & $\begin{array}{c}\text { Per- } \\
\text { cent }\end{array}$ & $\begin{array}{c}\text { Valid } \\
\text { Percent }\end{array}$ & $\begin{array}{c}\text { Cumulative } \\
\text { Percent }\end{array}$ \\
\hline \multirow{3}{*}{$\frac{.0}{\sqrt{\pi}}>$} & Tidak Setuju & 7 & 11.7 & 11.7 & 11.7 \\
\cline { 2 - 6 } & Setuju & 31 & 51.7 & 51.7 & 63.3 \\
\cline { 2 - 6 } & $\begin{array}{l}\text { Sangat } \\
\text { Setuju }\end{array}$ & 22 & 36.7 & 36.7 & 100.0 \\
\cline { 2 - 6 } & Total & 60 & 100.0 & 100.0 & \\
\hline
\end{tabular}


Dampak orang yang mengalami cyberbullying (harga diri rendah)

\begin{tabular}{|c|l|c|c|c|c|}
\hline \multicolumn{2}{|c|}{} & $\begin{array}{c}\text { Freq- } \\
\text { uency }\end{array}$ & $\begin{array}{c}\text { Per- } \\
\text { cent }\end{array}$ & $\begin{array}{c}\text { Valid } \\
\text { Per- } \\
\text { cent }\end{array}$ & $\begin{array}{c}\text { Cumulative } \\
\text { Percent }\end{array}$ \\
\hline \multirow{7}{*}{ Valid } & $\begin{array}{l}\text { Tidak } \\
\text { Setuju }\end{array}$ & 6 & 10.0 & 10.0 & 10.0 \\
\cline { 2 - 6 } & Setuju & 41 & 68.3 & 68.3 & 78.3 \\
\cline { 2 - 6 } & $\begin{array}{l}\text { Sangat } \\
\text { Setuju }\end{array}$ & 13 & 21.7 & 21.7 & 100.0 \\
\cline { 2 - 7 } & Total & $\mathbf{6 0}$ & $\mathbf{1 0 0 . 0}$ & $\mathbf{1 0 0 . 0}$ & \\
\hline
\end{tabular}

Dari data diatas dapat disimpulkan bahwa pernyataan "setuju" lebih besar dari pernyataan lainnya. Hal ini menunjukkan kebenaran bahwa cyberbullying dapat berdampak pada harga diri korban yang menjadi rendah. Korban yang mengalami cyberbullying dapat memiliki harga diri yang rendah karena ia terus ditekan oleh pesanpesan negatif dari pelaku cyberbullying.

Hal ini sesuai dengan teori yang diungkapkan oleh Rudi, 2010, bahwa harga diri rendah adalah salah satu dampak cyberbullying terhadap korbannya.

\section{Dampak orang yang mengalami cyberbullying (depresi)}

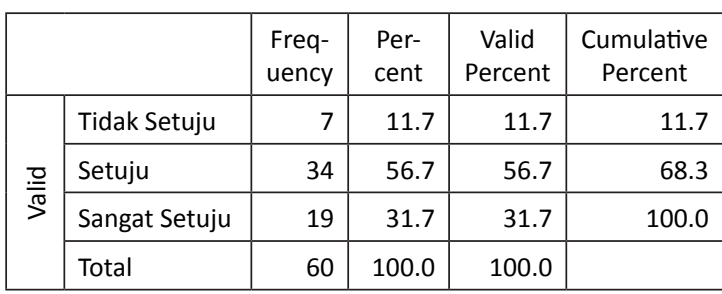

Data diatas, pernyataan "setuju" lebih besar dari pernyataan lainnya. Hal ini menunjukkan kebenaran bahwa cyberbullying dapat berdampak pada psikis korban yang menjadi depresi. Orang yang mengalami cyberbullying dapat menjadi depresi karena ia terus mendapat pesanpesan buruk dan negatif terus-menerus sehingga membuatnya tertekan dan berakhir pada keadaan depresi.

Hal ini sesuai dengan teori yang diungkapkan oleh Rudi, 2010, bahwa depresi adalah salah satu dampak cyberbullying terhadap korbannya.

13. Dampak orang yang mengalami cyberbullying (bunuh diri)

\begin{tabular}{|c|c|c|c|c|c|}
\hline & $\begin{array}{l}\text { Freq- } \\
\text { uency }\end{array}$ & $\begin{array}{l}\text { Per- } \\
\text { cent }\end{array}$ & $\begin{array}{l}\text { Valid } \\
\text { Percent }\end{array}$ & $\begin{array}{c}\text { Cumulative } \\
\text { Percent }\end{array}$ \\
\hline \multirow{5}{*}{$\frac{.0}{\sqrt{5}}$} & $\begin{array}{l}\text { Sangat Tidak } \\
\text { Setuju }\end{array}$ & 3 & 5.0 & 5.0 & 5.0 \\
\hline & Tidak Setuju & 13 & 21.7 & 21.7 & 26.7 \\
\hline & Setuju & 30 & 50.0 & 50.0 & 76.7 \\
\hline & $\begin{array}{l}\text { Sangat } \\
\text { Setuju }\end{array}$ & 14 & 23.3 & 23.3 & 100.0 \\
\hline & Total & 60 & 100.0 & 100.0 & \\
\hline
\end{tabular}

Dari data ini, dapat disimpulkan bahwa pernyataan "setuju" lebih besar dari pernyataan lain. Hal ini menunjukkan kebenaran bahwa cyberbullying dapat berdampak pada kematian karena banyak korban yang akhirnya bunuh diri. Terkadang korban menjadi depresi dan terkadang nekad mengakhiri hidupnya.

Hal ini sesuai dengan teori yang diungkapkan oleh Rudi, 2010, bahwa bunuh diri adalah salah satu dampak cyberbullying terhadap korbannya.

\section{Bentuk cyberbullying (mengirim kata penuh amarah)}

\begin{tabular}{|c|c|c|c|c|c|}
\hline & $\begin{array}{l}\text { Freq- } \\
\text { uency }\end{array}$ & $\begin{array}{l}\text { Per- } \\
\text { cent }\end{array}$ & $\begin{array}{l}\text { Valid } \\
\text { Percent }\end{array}$ & $\begin{array}{c}\text { Cumulative } \\
\text { Percent }\end{array}$ \\
\hline \multirow{5}{*}{$\frac{i \overline{0}}{\bar{N}}$} & $\begin{array}{l}\text { Sangat Tidak } \\
\text { Setuju }\end{array}$ & 3 & 5.0 & 5.0 & 5.0 \\
\hline & Tidak Setuju & 2 & 3.3 & 3.3 & 8.3 \\
\hline & Setuju & 44 & 73.3 & 73.3 & 81.7 \\
\hline & $\begin{array}{l}\text { Sangat } \\
\text { Setuju }\end{array}$ & 11 & 18.3 & 18.3 & 100.0 \\
\hline & Total & 60 & 100.0 & 100.0 & \\
\hline
\end{tabular}

Dari data diatas dapat disimpulkan bahwa pernyataan "setuju" lebih besar dari pernyataan lain. Hal ini menunjukkan kebenaran bahwa mengirim pesan teks berupa kata kasar yang penuh amarah 
kepada orang lain melalui media sosial adalah salah satu bentuk cyberbullying. Hal ini dikarenakan kata kasar penuh amarah dapat menyakiti orang lain.

Hal ini sesuai dengan teori yang diungkapkan oleh Dewi dan Purwanti, 2014, yang menyatakan bahwa mengirim pesan berupa kata kasar yang penuh amarah merupakan salah satu bentuk cyberbullying.

\section{Bentuk cyberbullying (mengirim pesan berbau pelecehan seksual)}

\begin{tabular}{|c|l|c|c|c|c|}
\hline \multicolumn{2}{|c|}{} & $\begin{array}{c}\text { Freq- } \\
\text { uency }\end{array}$ & $\begin{array}{c}\text { Per- } \\
\text { cent }\end{array}$ & $\begin{array}{c}\text { Valid } \\
\text { Percent }\end{array}$ & $\begin{array}{c}\text { Cumulative } \\
\text { Percent }\end{array}$ \\
\hline \multirow{4}{*}{$\begin{array}{l}\text { Sangat Tidak } \\
\text { Setuju }\end{array}$} & 3 & 5.0 & 5.0 & 5.0 \\
\cline { 2 - 6 }$>\overline{\sqrt{5}}$ & Tidak Setuju & 12 & 20.0 & 20.0 & 25.0 \\
\cline { 2 - 6 } & Setuju & 34 & 56.7 & 56.7 & 81.7 \\
\cline { 2 - 6 } & Sangat Setuju & 11 & 18.3 & 18.3 & 100.0 \\
\cline { 2 - 6 } & Total & $\mathbf{6 0}$ & $\mathbf{1 0 0 . 0}$ & $\mathbf{1 0 0 . 0}$ & \\
\hline
\end{tabular}

Dari data diatas dapat disimpulkan bahwa pernyataan "setuju" lebih besar dari pernyataan lain. Hal ini menunjukkan kebenaran bahwa mengirim pesan-pesan yang berisi pesan pelecehan seksual secara terus menerus kepada orang lain melalui media sosial adalah salah satu bentuk cyberbullying.

Hal ini sesuai dengan teori yang diungkapkan oleh Dewi dan Purwanti, 2014, yang menyatakan bahwa mengirim pesan-pesan berisi pesan pelecehan seksual merupakan salah satu bentuk cyberbullying.

\section{Bentuk cyberbullying (mengirim pesan kekerasan)}

\begin{tabular}{|c|c|c|c|c|c|}
\hline & $\begin{array}{l}\text { Freq- } \\
\text { uency }\end{array}$ & $\begin{array}{l}\text { Per- } \\
\text { cent }\end{array}$ & $\begin{array}{l}\text { Valid } \\
\text { Percent }\end{array}$ & $\begin{array}{c}\text { Cumulative } \\
\text { Percent }\end{array}$ \\
\hline \multirow{5}{*}{$\frac{\text { 음 }}{\frac{\pi}{5}}$} & $\begin{array}{l}\text { Sangat Tidak } \\
\text { Setuju }\end{array}$ & 3 & 5.0 & 5.0 & 5.0 \\
\hline & Tidak Setuju & 3 & 5.0 & 5.0 & 10.0 \\
\hline & Setuju & 42 & 70.0 & 70.0 & 80.0 \\
\hline & Sangat Setuju & 12 & 20.0 & 20.0 & 100.0 \\
\hline & Total & 60 & 100.0 & 100.0 & \\
\hline
\end{tabular}

Dari data diatas dapat disimpulkan bahwa pernyataan "setuju" lebih besar dari pernyataan lain. Hal ini menunjukkan kebenaran bahwa mengirim pesan-pesan yang berisi pesan kekerasan secara terus menerus kepada orang lain melalui media sosial adalah salah satu bentuk cyberbullying. Hal ini dikarenakan pesanpesan berisi pesan kekerasan tersebut dapat mengganggu bahkan menyakiti orang lain, pesan tersebut juga mungkin dapat membuat orang lain merasa tertekan.

Hal ini sesuai dengan teori yang diungkapkan oleh Dewi dan Purwanti, 2014, yang menyatakan bahwa mengirim pesanpesan berisi pesan kekerasan merupakan salah satu bentuk cyberbullying.

17. Bentuk cyberbullying (mengumbar keburukan orang lain)

\begin{tabular}{|c|c|c|c|c|c|}
\hline & $\begin{array}{l}\text { Freq- } \\
\text { uency }\end{array}$ & $\begin{array}{l}\text { Per- } \\
\text { cent }\end{array}$ & $\begin{array}{l}\text { Valid } \\
\text { Percent }\end{array}$ & $\begin{array}{c}\text { Cumulative } \\
\text { Percent }\end{array}$ \\
\hline \multirow{5}{*}{$\frac{.0}{\frac{0}{\pi}}$} & $\begin{array}{l}\text { Sangat Tidak } \\
\text { Setuju }\end{array}$ & 1 & 1.7 & 1.7 & 1.7 \\
\hline & Tidak Setuju & 3 & 5.0 & 5.0 & 6.7 \\
\hline & Setuju & 40 & 66.7 & 66.7 & 73.3 \\
\hline & Sangat Setuju & 16 & 26.7 & 26.7 & 100.0 \\
\hline & Total & 60 & 100.0 & 100.0 & \\
\hline
\end{tabular}

Dari data diatas dapat disimpulkan bahwa pernyataan "setuju" lebih besar dari pernyataan lain. Hal ini menunjukkan kebenaran bahwa mengumbar aib orang lain di media sosial dengan tujuan merusak nama baik orang tersebut merupakan salah satu bentuk cyberbullying. Hal ini dikarenakan pesan yang bersifat mengumbar keburukan orang lain dapat merusak nama baik orang tersebut sehingga hal itu dapat berdampak buruk terhadap orang tersebut.

Hal ini sesuai dengan teori yang 
diungkapkan oleh Dewi dan Purwanti, 2014, yang menyatakan bahwa mengumbar keburukan orang lain di media sosial dan media internet dengan tujuan merusak nama baik orang tersebut merupakan salah satu bentuk cyberbullying.

18. Bentuk cyberbullying (menggunakan account palsu)

\begin{tabular}{|c|l|c|c|c|c|}
\hline \multicolumn{2}{|c|}{} & $\begin{array}{c}\text { Freq- } \\
\text { uency }\end{array}$ & $\begin{array}{c}\text { Per- } \\
\text { cent }\end{array}$ & $\begin{array}{c}\text { Valid } \\
\text { Percent }\end{array}$ & $\begin{array}{c}\text { Cumulative } \\
\text { Percent }\end{array}$ \\
\hline \multirow{4}{*}{$\begin{array}{l}\text { Songat Tidak } \\
\text { Setuju }\end{array}$} & 1 & 1.7 & 1.7 & 1.7 \\
\cline { 2 - 6 } & Tidak Setuju & 2 & 3.3 & 3.3 & 5.0 \\
\cline { 2 - 6 } & Setuju & 41 & 68.3 & 68.3 & 73.3 \\
\cline { 2 - 6 } & Sangat Setuju & 16 & 26.7 & 26.7 & 100.0 \\
\cline { 2 - 6 } & Total & $\mathbf{6 0}$ & $\mathbf{1 0 0 . 0}$ & $\mathbf{1 0 0 . 0}$ & \\
\hline
\end{tabular}

Dari data diatas dapat disimpulkan bahwa pernyataan "setuju" lebih besar dari pernyataan lain. Hal ini menunjukkan kebenaran bahwa menggunakan account palsu untuk mengirim pesan-pesan tidak baik di media sosial merupakan salah satu bentuk cyberbullying. Hal ini dikarenakan menggunakan account palsu atas nama orang lain kemudian mengirim pesan tidak baik kepada orang lainnya dapat mengganggu dan menyakiti orang tersebut, hal ini juga pasti dapat berdampak buruk terhadap orang yang dipakai namanya untuk kejahatan tersebut.

Hal ini sesuai dengan teori yang diungkapkan oleh Dewi dan Purwanti, 2014, yang menyatakan bahwa menggunakan account palsu untuk mengirim pesan-pesan tidak baik di media sosial merupakan salah satu bentuk cyberbullying.

\section{Bentuk cyberbullying (membujuk orang} untuk mendapat rahasia pribadinya)

\begin{tabular}{|c|c|c|c|c|c|}
\hline & $\begin{array}{l}\text { Freq- } \\
\text { uency }\end{array}$ & $\begin{array}{l}\text { Per- } \\
\text { cent }\end{array}$ & $\begin{array}{l}\text { Valid } \\
\text { Percent }\end{array}$ & $\begin{array}{c}\text { Cumulative } \\
\text { Percent }\end{array}$ \\
\hline \multirow{5}{*}{$\frac{\text { 음 }}{\frac{5}{5}}$} & $\begin{array}{l}\text { Sangat Tidak } \\
\text { Setuju }\end{array}$ & 1 & 1.7 & 1.7 & 1.7 \\
\hline & Tidak Setuju & 21 & 35.0 & 35.0 & 36.7 \\
\hline & Setuju & 33 & 55.0 & 55.0 & 91.7 \\
\hline & Sangat Setuju & 5 & 8.3 & 8.3 & 100.0 \\
\hline & Total & 60 & 100.0 & 100.0 & \\
\hline
\end{tabular}

\section{Bentuk cyberbullying (menyebar} rahasia orang)

\begin{tabular}{|c|l|c|c|c|c|}
\hline \multicolumn{2}{|c|}{} & $\begin{array}{c}\text { Freq- } \\
\text { uency }\end{array}$ & $\begin{array}{c}\text { Per- } \\
\text { cent }\end{array}$ & $\begin{array}{c}\text { Valid } \\
\text { Percent }\end{array}$ & $\begin{array}{c}\text { Cumulative } \\
\text { Percent }\end{array}$ \\
\hline \multirow{4}{*}{\begin{tabular}{c}
$\overline{\bar{J}}>$ \\
\cline { 2 - 6 }
\end{tabular}} & Tidak Setuju & 6 & 10.0 & 10.0 & 10.0 \\
\cline { 2 - 6 } & Setuju & 40 & 66.7 & 66.7 & 76.7 \\
\cline { 2 - 6 } & Sangat Setuju & 14 & 23.3 & 23.3 & 100.0 \\
\cline { 2 - 6 } & Total & 60 & 100.0 & 100.0 & \\
\hline
\end{tabular}

Dari 2 tabel diatas dapat disimpulkan bahwa pernyataan "setuju" lebih besar dari pernyataan lain. Hal ini menunjukkan kebenaran bahwa membujuk seseorang dengan tipu daya dengan tujuan untuk mendapat rahasia pribadi dan menyebarkan rahasia pribadi orang lain di media sosial merupakan bentuk cyberbullying.

Hal ini sesuai dengan teori yang diungkapkan oleh Dewi dan Purwanti, 2014, yang menyatakan bahwa membujuk seseorang dengan tipu daya agar mendapat rahasia pribadi dan menyebarkan rahasia pribadi orang lain di media sosial merupakan salah satu bentuk cyberbullying. 
20. Bentuk cyberbullying (membujuk orang untuk mendapat foto pribadinya)

\begin{tabular}{|c|c|c|c|c|c|}
\hline & $\begin{array}{l}\text { Fre- } \\
\text { quency }\end{array}$ & $\begin{array}{l}\text { Per- } \\
\text { cent }\end{array}$ & $\begin{array}{c}\text { Valid } \\
\text { Percent }\end{array}$ & $\begin{array}{c}\text { Cumulative } \\
\text { Percent }\end{array}$ \\
\hline \multirow{5}{*}{$\frac{\text { 은 }}{5}$} & $\begin{array}{l}\text { Sangat Tidak } \\
\text { Setuju }\end{array}$ & 1 & 1.7 & 1.7 & 1.7 \\
\hline & Tidak Setuju & 18 & 30.0 & 30.0 & 31.7 \\
\hline & Setuju & 35 & 58.3 & 58.3 & 90.0 \\
\hline & Sangat Setuju & 6 & 10.0 & 10.0 & 100.0 \\
\hline & Total & 60 & 100.0 & 100.0 & \\
\hline
\end{tabular}

\section{Bentuk cyberbullying (menyebar foto} pribadi orang)

\begin{tabular}{|c|c|c|c|c|c|}
\hline & $\begin{array}{l}\text { Freq- } \\
\text { uency }\end{array}$ & $\begin{array}{l}\text { Per- } \\
\text { cent }\end{array}$ & $\begin{array}{l}\text { Valid } \\
\text { Percent }\end{array}$ & $\begin{array}{c}\text { Cumulative } \\
\text { Percent }\end{array}$ \\
\hline \multirow{5}{*}{$\frac{\overline{0}}{5}$} & $\begin{array}{l}\text { Sangat Tidak } \\
\text { Setuju }\end{array}$ & 3 & 5.0 & 5.0 & 5.0 \\
\hline & Tidak Setuju & 6 & 10.0 & 10.0 & 15.0 \\
\hline & Setuju & 41 & 68.3 & 68.3 & 83.3 \\
\hline & Sangat Setuju & 10 & 16.7 & 16.7 & 100.0 \\
\hline & Total & 60 & 100.0 & 100.0 & \\
\hline
\end{tabular}

Dari data diatas dapat disimpulkan bahwa pernyataan "setuju" lebih besar dari pernyataan lain. Hal ini menunjukkan kebenaran bahwa membujuk seseorang dengan tipu daya dengan tujuan untuk mendapat foto pribadi orang dan menyebarkan foto-foto pribadi orang lain di media sosial merupakan bentuk cyberbullying.

Hal ini sesuai dengan teori yang diungkapkan oleh Dewi dan Purwanti, 2014, yang menyatakan bahwa membujuk seseorang dengan tipu daya agar mendapat foto pribadi orang dan menyebarkan fotofoto pribadi orang lain di media sosial merupakan salah satu bentuk cyberbullying.
21. Bentuk cyberbullying (menyebarkan aib orang)

\begin{tabular}{|c|l|c|c|c|c|}
\hline \multicolumn{2}{|c|}{} & $\begin{array}{c}\text { Freq- } \\
\text { uency }\end{array}$ & $\begin{array}{c}\text { Per- } \\
\text { cent }\end{array}$ & $\begin{array}{c}\text { Valid } \\
\text { Percent }\end{array}$ & $\begin{array}{c}\text { Cumulative } \\
\text { Percent }\end{array}$ \\
\hline \multirow{4}{*}{\begin{tabular}{c}
$\overline{\frac{\Xi}{5}}$ \\
\cline { 1 - 6 }
\end{tabular}} & Tidak Setuju & 4 & 6.7 & 6.7 & 6.7 \\
\cline { 2 - 6 } & Setuju & 41 & 68.3 & 68.3 & 75.0 \\
\cline { 2 - 6 } & Sangat Setuju & 15 & 25.0 & 25.0 & 100.0 \\
\cline { 2 - 6 } & Total & 60 & 100.0 & 100.0 & \\
\hline
\end{tabular}

Dari data diatas dapat disimpulkan bahwa pernyataan "setuju" lebih besar dari pernyataan lain. Hal ini menunjukkan kebenaran bahwa menyebarkan aib orang lain di media sosial merupakan bentuk cyberbullying. Hal ini dikarenakan aib yang telah tersebar tersebut dapat berdampak kepada emosi korban karena ia mungkin saja mendapat komentar buruk dari orang lain karena aib tersebut, kemudian ia dapat saja merasa terhina dan tertekan karena komentar dari orang lain.

Hal ini sesuai dengan teori yang diungkapkan oleh Dewi dan Purwanti, 2014, yang menyatakan bahwa menyebarkan aib orang lain di media sosial merupakan salah satu bentuk cyberbullying.

22. Bentuk cyberbullying (meneror orang lain)

\begin{tabular}{|c|l|c|c|c|c|}
\hline \multicolumn{2}{|c|}{} & $\begin{array}{c}\text { Freq- } \\
\text { uency }\end{array}$ & $\begin{array}{c}\text { Per- } \\
\text { cent }\end{array}$ & $\begin{array}{c}\text { Valid } \\
\text { Percent }\end{array}$ & $\begin{array}{c}\text { Cumula- } \\
\text { tive Percent }\end{array}$ \\
\hline \multirow{4}{*}{$\underset{*}{*}>$} & Tidak Setuju & 1 & 1.7 & 1.7 & 1.7 \\
\cline { 2 - 6 } & Setuju & 45 & 75.0 & 75.0 & 76.7 \\
\cline { 2 - 6 } & Sangat Setuju & 14 & 23.3 & 23.3 & 100.0 \\
\cline { 2 - 6 } & Total & 60 & 100.0 & 100.0 & \\
\hline
\end{tabular}

Dari data diatas dapat disimpulkan bahwa pernyataan "setuju" lebih besar dari pernyataan lain. Hal ini menunjukkan kebenaran bahwa meneror orang secara terus menerus di media sosial sehingga menimbulkan ketakutan besar merupakan salah satu bentuk cyberbullying. 
Hal ini sesuai dengan teori yang diungkapkan oleh Dewi dan Purwanti, 2014, yang menyatakan bahwa meneror orang secara terus menerus di media sosial sehingga menimbulkan ketakutan besar merupakan salah satu bentuk cyberbullying.

\section{Bentuk cyberbullying (memanggil} dengan panggilan kasar)

\begin{tabular}{|c|c|c|c|c|c|}
\hline & $\begin{array}{l}\text { Freq- } \\
\text { uency }\end{array}$ & $\begin{array}{l}\text { Per- } \\
\text { cent }\end{array}$ & $\begin{array}{l}\text { Valid } \\
\text { Percent }\end{array}$ & $\begin{array}{c}\text { Cumula-tive } \\
\text { Percent }\end{array}$ \\
\hline \multirow{5}{*}{$\frac{0}{9}$} & $\begin{array}{l}\text { Sangat Tidak } \\
\text { Setuju }\end{array}$ & 1 & 1.7 & 1.7 & 1.7 \\
\hline & Tidak Setuju & 12 & 20.0 & 20.0 & 21.7 \\
\hline & Setuju & 32 & 53.3 & 53.3 & 75.0 \\
\hline & Sangat Setuju & 15 & 25.0 & 25.0 & 100.0 \\
\hline & Total & 60 & 100.0 & 100.0 & \\
\hline
\end{tabular}

Dari data diatas dapat disimpulkan bahwa pernyataan "setuju" lebih besar dari pernyataan lainnya. Hal ini menunjukkan kebenaran bahwa memanggil orang lain dengan panggilan kasar di media sosial merupakan bentuk cyberbullying. Panggilan kasar yang biasa terlihat di media sosial contohnya adalah memanggil orang lain dengan nama binatang (anjing, babi, monyet, dll), bentuk tubuh orang (gendut, pendek, ceking, dll) dan kata-kata kasar lainnya.

Hal ini sesuai dengan teori yang diungkapkan oleh Akbar dan Utari, 2015, yang menyatakan bahwa memanggil orang lain dengan panggilan kasar di media sosial merupakan salah satu bentuk cyberbullying.
24. Bentuk cyberbullying (mengirim pesan kata "mati")

\begin{tabular}{|c|l|c|c|c|c|}
\hline \multicolumn{2}{|c|}{} & $\begin{array}{c}\text { Freq- } \\
\text { uency }\end{array}$ & $\begin{array}{c}\text { Per- } \\
\text { cent }\end{array}$ & $\begin{array}{c}\text { Valid } \\
\text { Percent }\end{array}$ & $\begin{array}{c}\text { Cumulative } \\
\text { Percent }\end{array}$ \\
\hline \multirow{4}{*}{$\begin{array}{l}\text { Sangat Tidak } \\
\text { Setuju }\end{array}$} & 1 & 1.7 & 1.7 & 1.7 \\
\cline { 2 - 6 }$>\bar{v}$ & Tidak Setuju & 15 & 25.0 & 25.0 & 26.7 \\
\cline { 2 - 6 } & Setuju & 33 & 55.0 & 55.0 & 81.7 \\
\cline { 2 - 6 } & Sangat Setuju & 11 & 18.3 & 18.3 & 100.0 \\
\cline { 2 - 6 } & Total & 60 & 100.0 & 100.0 & \\
\hline
\end{tabular}

Dari data diatas dapat disimpulkan bahwa pernyataan "setuju" lebih besar dari pernyataan lainnya. Hal ini menunjukkan kebenaran bahwa mengancam dengan mengirim kata "mati" di media sosial merupakan bentuk cyberbullying. Hal ini karena kata-kata seperti "mati aja lo", "orang kaya lo mending mati ajadeh", "mati aja lo, gak pantes hidup" dan kalimat berisi kata "mati” yang kasar lainnya dapat menyakiti hati korban dan orang lain, tentu juga akan mengganggu psikisnya karena dirinya merasa terancam dan tidak aman, bisa saja karena kata-kata tersebut korban menjadi tertekan dan depresi kemudian terpikir untuk mati saja dan memutuskan untuk bunuh diri. Kejadian ini tentu merupakan bentuk cyberbullying.

Hal ini sesuai dengan teori yang diungkapkan oleh Akbar dan Utari, 2015, yang menyatakan bahwa mengancam dengan mengirim kata "mati" di media sosial merupakan salah satu bentuk cyberbullying. 
25. Bentuk cyberbullying (menganggap orang lain buruk)

\begin{tabular}{|c|l|c|c|c|c|}
\hline \multicolumn{2}{|c|}{} & $\begin{array}{c}\text { Freq- } \\
\text { uency }\end{array}$ & $\begin{array}{c}\text { Per- } \\
\text { cent }\end{array}$ & $\begin{array}{c}\text { Valid } \\
\text { Percent }\end{array}$ & $\begin{array}{c}\text { Cumulative } \\
\text { Percent }\end{array}$ \\
\hline \multirow{4}{*}{\begin{tabular}{c}
$\underline{\underline{5}}>$ \\
\cline { 1 - 5 }
\end{tabular}} & Tidak Setuju & 9 & 15.0 & 15.0 & 15.0 \\
\cline { 2 - 6 } & Setuju & 39 & 65.0 & 65.0 & 80.0 \\
\cline { 2 - 6 } & Sangat Setuju & 12 & 20.0 & 20.0 & 100.0 \\
\cline { 2 - 6 } & Total & 60 & 100.0 & 100.0 & \\
\hline
\end{tabular}

Dari data diatas dapat disimpulkan bahwa pernyataan "setuju" lebih besar dari pernyataan lainnya. Hal ini menunjukkan kebenaran bahwa menganggap orang lain lebih buruk daripada dirinya di media sosial merupakan bentuk cyberbullying. Hal ini karena pelaku cyberbullying kadang mengirim pesan yang merendahkan orang lain karena ia merasa orang tersebut lebih buruk dari dirinya. Kata-kata yang pelaku lontarkan pun sangat jahat karena bersifat merendahkan korban.

Hal ini sesuai dengan teori yang diungkapkan oleh Akbar dan Utari, 2015, yang menyatakan bahwa menganggap orang lain lebih buruk daripada dirinya di media sosial merupakan salah satu bentuk cyberbullying.

\section{Bentuk cyberbullying (menganggap dirinya hebat)}

\begin{tabular}{|c|c|c|c|c|c|}
\hline & & $\begin{array}{l}\text { Freq- } \\
\text { uency }\end{array}$ & $\begin{array}{l}\text { Per- } \\
\text { cent }\end{array}$ & $\begin{array}{l}\text { Valid } \\
\text { Percent }\end{array}$ & $\begin{array}{l}\text { Cumulative } \\
\text { Percent }\end{array}$ \\
\hline \multirow{4}{*}{$\frac{\text { 음 }}{>}$} & Tidak Setuju & 11 & 18.3 & 18.3 & 18.3 \\
\hline & Setuju & 31 & 51.7 & 51.7 & 70.0 \\
\hline & Sangat Setuju & 18 & 30.0 & 30.0 & 100.0 \\
\hline & Total & 60 & 100.0 & 100.0 & \\
\hline
\end{tabular}

Dari data diatas dapat disimpulkan bahwa pernyataan "setuju" lebih besar dari pernyataan lainnya. Hal ini menunjukkan kebenaran bahwa menganggap diri lebih hebat dibandingkan orang lain di media sosial merupakan bentuk cyberbullying.
Hal ini sesuai dengan teori yang diungkapkan oleh Akbar dan Utari, 2015, yang menyatakan bahwa menganggap diri lebih hebat dibandingkan orang lain di media sosial merupakan salah satu bentuk cyberbullying.

27. Media yang paling sering berisi cyberbullying (Facebook)

\begin{tabular}{|c|c|c|c|c|c|}
\hline & $\begin{array}{l}\text { Freq- } \\
\text { uency }\end{array}$ & $\begin{array}{l}\text { Per- } \\
\text { cent }\end{array}$ & $\begin{array}{l}\text { Valid } \\
\text { Percent }\end{array}$ & $\begin{array}{l}\text { Cumula } \\
\text { tive Percent }\end{array}$ \\
\hline \multirow{4}{*}{$\frac{\text { 음 }}{>\sqrt{5}}$} & Tidak Setuju & 15 & 25.0 & 25.0 & 25.0 \\
\hline & Setuju & 35 & 58.3 & 58.3 & 83.3 \\
\hline & Sangat Setuju & 10 & 16.7 & 16.7 & 100.0 \\
\hline & Total & 60 & 100.0 & 100.0 & \\
\hline
\end{tabular}

Dari data diatas dapat disimpulkan bahwa pernyataan "setuju" lebih besar dari pernyataan lainnya. Hal ini menunjukkan kebenaran bahwa Facebook merupakan media sosial yang paling banyak berisi tindak cyberbullying. Hal ini dikarenakan Facebook merupakan media sosial yang masih banyak diminati orang. Di Facebook sering terjadi kasus penyebaran foto-foto dan rahasia pribadi orang lain yang dapat berdampak negative terhadap kehidupan orang tersebut.

Hal ini sesuai dengan teori yang diungkapkan oleh Giovanni, 2014, yang menyatakan bahwa cyberbullying merupakan intimidasi yang dilakukan seseorang pada orang lain yang dilakukan melalui chatroom, media sosial (Facebook, Ask.fm, Instagram, Twitter, Path, dan YouTube), e-mail, website dalam bentuk seperti fitnah, penghinaan, pengancaman atau dibocorkannya aib mengenai seseorang. 
28. Media yang paling sering berisi cyberbullying (Instagram)

\begin{tabular}{|c|c|c|c|c|c|}
\hline & $\begin{array}{l}\text { Freq- } \\
\text { uency }\end{array}$ & Percent & $\begin{array}{l}\text { Valid } \\
\text { Percent }\end{array}$ & $\begin{array}{c}\text { Cumulative } \\
\text { Percent }\end{array}$ \\
\hline \multirow{4}{*}{$\frac{.0}{5}$} & Tidak Setuju & 11 & 18.3 & 18.3 & 18.3 \\
\hline & Setuju & 29 & 48.3 & 48.3 & 66.7 \\
\hline & Sangat Setuju & 20 & 33.3 & 33.3 & 100.0 \\
\hline & Total & 60 & 100.0 & 100.0 & \\
\hline
\end{tabular}

Dari data diatas dapat disimpulkan bahwa pernyataan "setuju" lebih besar dari pernyataan lainnya. Hal ini menunjukkan kebenaran bahwa Instagram merupakan media sosial yang paling banyak berisi tindak cyberbullying. Hal ini dikarenakan Instagram merupakan media yang paling banyak diminati pengguna internet, di Instagram juga dapat men-share foto, video dan konten lain dengan leluasa.

Hal ini sesuai dengan teori yang diungkapkan oleh Giovanni, 2014, yang menyatakan bahwa cyberbullying merupakan intimidasi yang dilakukan seseorang pada orang lain yang dilakukan melalui chatroom, media sosial (Facebook, Ask.fm, Instagram, Twitter, Path, dan YouTube), e-mail, website.

\section{Media yang paling sering berisi} cyberbullying (YouTube)

\begin{tabular}{|c|c|c|c|c|c|}
\hline & $\begin{array}{c}\text { Fre- } \\
\text { quency }\end{array}$ & $\begin{array}{l}\text { Per- } \\
\text { cent }\end{array}$ & $\begin{array}{l}\text { Valid } \\
\text { Percent }\end{array}$ & $\begin{array}{c}\text { Cumulative } \\
\text { Percent }\end{array}$ \\
\hline \multirow{5}{*}{$\frac{\overline{0}}{5}$} & $\begin{array}{l}\text { Sangat Tidak } \\
\text { Setuju }\end{array}$ & 2 & 3.3 & 3.3 & 3.3 \\
\hline & Tidak Setuju & 6 & 10.0 & 10.0 & 13.3 \\
\hline & Setuju & 39 & 65.0 & 65.0 & 78.3 \\
\hline & Sangat Setuju & 13 & 21.7 & 21.7 & 100.0 \\
\hline & Total & 60 & 100.0 & 100.0 & \\
\hline
\end{tabular}

Dari data diatas dapat disimpulkan bahwa pernyataan "setuju" lebih besar dari pernyataan lainnya. Hal ini menunjukkan kebenaran bahwa YouTube merupakan media sosial yang paling banyak berisi tindak cyberbullying. Di YouTube sering ditemukan tindak cyberbullying pada komentar-komentar negative yang dilontarkan orang pada postingan video seseorang. Komentar tersebut kadang terkesan sangat kejam sehingga mungkin dapat menyakiti korban. Di dalam video yang ada di YouTube juga sering terdapat tindak cyberbullying seperti kata-kata yag menghina dan merendahkan orang lain.

Hal ini sesuai dengan teori yang diungkapkan oleh Giovanni, 2014, yang menyatakan bahwa cyberbullying merupakan intimidasi yang dilakukan seseorang pada orang lain yang dilakukan melalui chatroom, media sosial (Facebook, Ask.fm, Instagram, Twitter, Path, dan YouTube), e-mail, website.

\section{Sifat pelaku cyberbullying (dominasi)}

\begin{tabular}{|c|c|c|c|c|c|}
\hline & $\begin{array}{l}\text { Frquen- } \\
\text { cy }\end{array}$ & $\begin{array}{l}\text { Per- } \\
\text { cent }\end{array}$ & $\begin{array}{l}\text { Valid } \\
\text { Percent }\end{array}$ & $\begin{array}{c}\text { Cumulative } \\
\text { Percent }\end{array}$ \\
\hline \multirow{4}{*}{$\frac{.0}{\frac{0}{n}}$} & Tidak Setuju & 11 & 18.3 & 18.3 & 18.3 \\
\hline & Setuju & 36 & 60.0 & 60.0 & 78.3 \\
\hline & Sangat Setuju & 13 & 21.7 & 21.7 & 100.0 \\
\hline & Total & 60 & 100.0 & 100.0 & \\
\hline
\end{tabular}

Dari data diatas dapat disimpulkan bahwa pernyataan "setuju" lebih besar dari pernyataan lainnya. Hal ini menunjukkan kebenaran bahwa pelaku cyberbullying memiliki niat untuk mendominasi korban. Hal ini dikarenakan pelaku memiliki sifat agresif yang selalu ingin mendominasi korban. Pelaku sering mengirim pesan negative, pelaku sering memperkeruh komentar orang lain terhadap korban, pelaku terus-menerus mengirim pesan buruk kepada korban, pelaku selalu ingin menujukkan kekuatannya kepada korban dengan menguasainya. 
Hal ini sesuai dengan teori yang diungkapkan oleh Akbar \& Utari, 2015, bahwa pelaku cyberbullying memiliki sifat agresif, dimana ia selalu ingin mendominasi orang lain. 31. Sifat korban cyberbullying (melindungi diri sendiri)

\begin{tabular}{|c|c|c|c|c|c|}
\hline & & $\begin{array}{c}\text { Fre- } \\
\text { quency }\end{array}$ & $\begin{array}{l}\text { Per- } \\
\text { cent }\end{array}$ & $\begin{array}{c}\text { Valid } \\
\text { Percent }\end{array}$ & $\begin{array}{c}\text { Cumulative } \\
\text { Percent }\end{array}$ \\
\hline \multirow{4}{*}{$\frac{.0}{5}$} & Tidak Setuju & 11 & 18.3 & 18.6 & 18.6 \\
\hline & Setuju & 37 & 61.7 & 62.7 & 81.4 \\
\hline & Sangat Setuju & 11 & 18.3 & 18.6 & 100.0 \\
\hline & Total & 59 & 98.3 & 100.0 & \\
\hline & Missing System & 1 & 1.7 & & \\
\hline \multicolumn{2}{|c|}{ Total } & 60 & 100.0 & & \\
\hline
\end{tabular}

Dari data diatas dapat disimpulkan bahwa pernyataan "setuju" lebih besar dari pernyataan lainnya. Hal ini menunjukkan kebenaran bahwa korban cyberbullying cenderungakan melindugi diri dari ancaman pelaku. Hal ini dikarenakan korban memiliki sifat defensif, dimana defensif dipilih korban untuk melindungi diri dari ancaman yang ditanggapinya dalam situasi komunikasi ketimbang memahami pesan orang lain. Bereaksi membela diri dengan menghina kembali pelaku yang terus menerus menghina korban. Korban kadang defensif untuk membela harga dirinya.

Hal ini sesuai dengan teori yang diungkapkan oleh Akbar \& Utari, 2015, bahwa korban cyberbullying memiliki sifat defensif, dimana ia selalu berusaha untuk melindungi diri dari ancaman orang lain

\section{PENUTUP}

Terdapat beberapa kesimpulan yang ditemukan sebagai berikut :

1. Usia pengguna Internet dan media sosial terbanyak di UPJ adalah 18-21 tahun, karena pada usia tersebut sedang marakmaraknya mengikuti tren.

2. Iphone yaitu sebanyak 31 orang atau $51.7 \%$, kemudian untuk pengguna Android yang berselisih sedikit yaitu sebanyak 29 orang atau $48.3 \%$.

3. Instagram adalah media sosial yang paling banyak digunakan

4. Mahasiswa biasanya mengakes internet selama 6-10 jam perhari.

5. Mahasiswa biasanya mengakes media sosial selama 6-10 jam perhari.

6. Sebagian besar mahasiswa UPJ telah mengetahui dan pernah melihat cyberbullying. Kemudian beberapa orang juga mengaku pernah menjadi korban dan pelaku cyberbullying karena ada motifmotif tertentu.

7. Tindak cyberbullying paling sering terjadi di Instagram.

8. Cyberbullying paling besar disebabkan oleh sakit hati, marah, dan dendam yang semakin didukung dengan kemudahan teknologi seperti akses internet 24 jam. Karena orang yang marah, sakit hati dan memiliki dendam lebih bermotif untuk melakukan cyberbullying untuk melampiaskan emosi, amarah, sakit hati dan membalaskan dendamnya kepada orang tersebut atau orang lain.

9. Cyberbullying dapat berdampak besar pada korban yaitu membuat harga dirinya menjadi rendah. Hal ini disebabkan karena korban menerima pesan dan perlakuan buruk dari orang lain secara terus menerus yang terkadang mungkin membuat dirinya merasa tidak berguna. Hal ini tentu berdampak pada kepercayaan dirinya dan kepada harga dirinya.

10. Dari beberapa bentuk cyberbullying yang 
telah dijelaskan sebelumnya, yang paling menggambarkan tindakan cyberbullying adalah meneror secara terus menerus sehingga menimbulkan ketakutan besar, mengirim pesan teks berupa kata kasar penuh amarah, dan mengirim pesan berisi pesan kekerasan. Hal ini dikarenakan meneror, mengirim pesan kasar penuh amarah, dan mengirim pesan kekerasan dapat berdampak negatif terhadap korban yang menerimanya.

11. Youtube, Facebook dan Instagram merupakan media sosial yang paling sering berisi tindak cyberbullying. Hal ini dikarenakan Youtube, Facebook, dan Instagram merupakan media sosial yang paling sering digunakan oleh orang. Media sosial sosial tersebut juga memiliki fitur yang mudah digunakan. Dalam Youtube, Facebook dan Instagram, orang lain bebas berkomentar pada post orang lain, terkadang komentar tersebut bersifat negatif bahkan hingga menyakiti orang tersebut. Hal ini sangat sering terjadi di media sosial, selain itu saling menghina juga sering ditemukan dalam komentar di media sosial Youtube, Facebook, dan Instagram.

12. Cyberbullying cenderung memiliki niat untuk mencelakai korban. Hal ini dikarenakan pelaku cyberbullying memang pasti punya niat jahat terhadap korbannya, ia cenderung suka menindas dan menyakiti orang lain.

13. Kemudian korban cyberbullying cenderung ingin melindungi diri dari ancaman pelaku. Hal ini dikarenakan terkadang korban terlalu berekasi terhadap perilaku pelaku, korban cenderung ingin melindungi diri dari ancaman pelaku dengan bereaksi terhadapnya, seperti membalas pesanpesan negatif pelaku negatif lainnya

\section{DAFTAR PUSTAKA}

Akbar, Muhammad, A. \& Utari, Prahastiwi. (2015). Cyberbullying pada Media Sosial (Studi Analisis Isi tentang Cyberbullying pada Remaja di Facebook). eJournal yang diunduh pada tanggal 7 Oktober 2016 dari http://www.jurnalkommas.com/docs/ JURNAL\%20-\%20FIX.pdf

Aulia, Fanny. (2014). Opini Siswa terhadap Tindakan Cyberbully di Media Sosial. eJournal yang diakses pada tanggal 27 September 2016 dari http://etd.repository. ugm.ac.id/index.php?mod=download\&su $\mathrm{b}=$ DownloadFile\&act $=$ view $\&$ typ $=\mathrm{html} \& \mathrm{i}$ $\mathrm{d}=79205 \& \mathrm{ftyp}=$ potongan $\&$ potongan $=\mathrm{S} 1-$ 2015-296988-chapter1.pdf

Dewi \& Purwanti. (2014). Pengaturan Cyber Bullying dalam Undang-Undang Nomor 11 Tahun 2008 tentang Informasi dan Transaksi Elektronik. eJournal yang diunduh pada tanggal 26 September 2016 dari http://ojs.unud.ac.id/index.php/ kerthawicara/article/download/9110/6870

Giovanni, Simorangkir. (2014). Tindakan Mahasiswa FISIP USU terhadap cyberbulling yang dialami melalui media online. eJournal yang diunduh pada tanggal 25 September 2016 dari http://repository. usu.ac.id/bitstream/123456789/42287/5/ Chapter\%20I.pdf

Kominfo. (2014). Pengguna Internet Indonesia Nomor Enam Dunia. Artikel yang diakses pada tanggal 26 September 2016 dari https://kominfo.go.id/content/detail/4286/ pengguna-internet-indonesia-nomorenam-dunia/0/sorotan_media

Kominfo. (2016). Kemkominfo: Penggunaan Internet di Indonesia Capai 82 Juta. Artikel yang diakses pada tanggal 26 September 2016 dari https://kominfo.go.id/index. $\mathrm{php} /$ content/detail/3980/Kemkominfo\%3 $\mathrm{A}+$ Pengguna + Internet $+\mathrm{di}+$ Indonesia $+\mathrm{Ca}$ pai $+82+$ Juta/0/berita_satker 
Lesmana, I Gusti Ngurah Aditya. (2012). Analisis Pengaruh Media Sosial Twitter Terhadap Pembentukkan Brand Attachment (Studi : PT. XL Axiata). Diunduh pada tanggal 21 Desember 2015 dari http://lib.ui.ac.id/ file?file $=$ digital $/ 20333231-\mathrm{T} 32242-\mathrm{I} \% 20$ Gusti $\% 20 \mathrm{Ngurah} \% 20$ Aditya $\% 20$ Lesmana.pdf

Rudi, Trisna. (Maret, 2010). Informasi Perihal Bullying. E-book yang diunduh pada tanggal 26 September 2016 dari https://bigloveadagio.files.wordpress. com/2010/03/informasi_perihal_bullying. pdf

Saputro, R. (Juli, 2011). Determinisme Teknologi: Kajian Filsafat Mengenai Pengaruh Teknologi terhadap Perkembangan Masyarakat. eJournal yang diunduh pada tanggal 2 Oktober 2016 dari http:// lib.ui.ac.id/file?file=digital/20172101T28737-Determinisme\%20teknologi.pdf
Sudarwanto, Sentot. (2009). Cyberbullying Kejahatan Dunia Maya Yang "Terlupakan". eJournal yang diunduh pada tanggal 20 Oktober 2016 dari http:// journal.unpar.ac.id/index.php/projustitia/ article/viewFile/1081/1048

Tim Internet Sehat. (11 Juli, 2012). 1 dari 10 Korban Cyberbully Lakukan Bunuh Diri!. Artikel yang diakses pada tanggal 29 September 2016 dari http://ictwatch. com/internetsehat/2012/07/11/1-dari-10korban-cyberbully-lakukan-bunuh-diri/ 